\title{
A Research In Relating Entrepreneurship, Marketing Capability, Innovative Capability And Sustained Competitive Advantage
}

Jia-Sheng Lee, Providence University, Taiwan, R.O.C.

Chia-Jung Hsieh, TRUMPF Taiwan Industries Co., Ltd., Taiwan, R.O.C.

\begin{abstract}
The purpose of this research is to investigate the relationships of entrepreneurship, marketing capability, innovative capability, and sustained competitive advantage; hopefully to propose some new points of views in managing enterprises. We investigate the top 1000 Taiwan manufacturers in 2009 issued by Commonwealth magazine of Taiwan in this research. In total, 116 effective samples are collected. We use SEM linear structure equation model, and LISREL 8.7 editions of software for data analyses, and verify our hypotheses. The empirical results show: 1.entrepreneurship directly influence marketing capability, innovative capability and sustained competitive advantage respectively; and indirectly influence sustained competitive advantage through marketing capability and innovative capability respectively; 2.although marketing capability does not influence sustained competitive advantage directly, but influence sustained competitive advantages indirectly through innovative capability; in the other way, innovative capability influence sustained competitive advantage directly. Therefore, we suggest that an enterprise needs to develop its organizational culture of entrepreneurship and the two kinds of capabilities, marketing and innovation, hopefully to enhance its sustained competitive advantage.
\end{abstract}

Keywords: entrepreneurship, marketing capability, innovative capability, sustained competitive advantage

\section{INTRODUCTION}

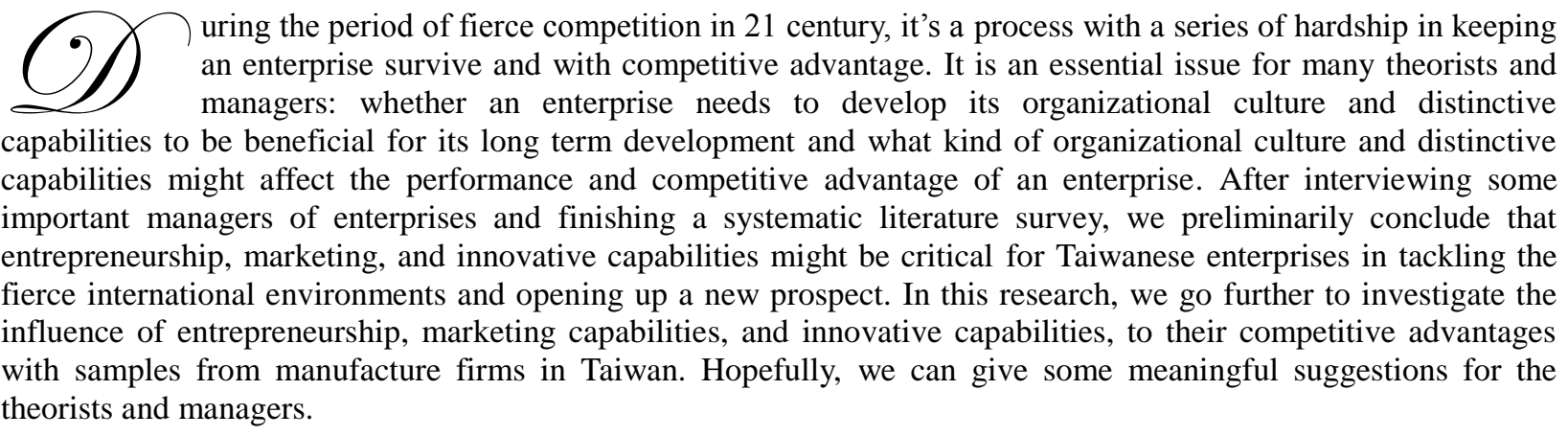

Entrepreneurship not only exists in new found technological firms, but also exists in the present and big firms that have long history (Drucker, 1985b). Drucker(1985a) points out that entrepreneurship is a kind of behavior based on some concepts and thoughts. Any decision maker who can boldly and actively deal with problems can learn to become an entrepreneur. Entrepreneurs can take the changes in environment as normal situations and try to utilize the opportunities in environments. The risks of starting a business mainly come from that only a few persons have the idea and spirit of entrepreneurship. Therefore, it is important to cultivate a common culture of entrepreneurship so that the middle and high level of managers have the value and behavior model of entrepreneurship. Entrepreneurs can find the source of innovation, the changes of environment, and clue of 
opportunity in environment, and can understand the principle of successful innovation and to use it. Entrepreneurship is an important influential factor for sustained competitive advantage. It is also a critical factor on which marketing and innovative capabilities depends (Weerawardena \& O'Cass, 2004). The capabilities of market orientation as marketing and innovative capabilities are also important means for entrepreneurs, by which they can change the environment and open up a new business or service (Drucker, 1985a).

Marketing capabilities are the resources and capabilities for marketing operation, including the tangible and intangible resources and capabilities of brand, sales, channel, service (Kapferer, 1992) to provide various marketing service. Weerawardena (2003) points out that the function of marketing is to acquire the complete market knowledge, create and provide valuable and excellent product and service to its target customers. A company that can respond the needs of market and predict the market situation generally enjoys longer competitive advantage and better profit (Day, 1994). Marketing capabilities for a company that is based on innovative capability is indispensible factors, and can help generate distinctive innovative capabilities and obtain growth and profits (Statistics Canada, 1994). On the other hand, the innovation of product is also good for marketing activities, and can enhance the business performance (Song and Parry, 1993; Calantone and di Benedetto, 1988; Schmidt, 1995). Therefore, innovation, marketing and competitive advantage exist close relationships.

Entrepreneurship, marketing and innovative capabilities might positively influence competitive advantage, but there few literatures discuss the relationships among them. In this research, we include these strategic constructs in the research structure and investigate their influence on business performance. We take marketing and innovative capabilities as meditative variables of entrepreneurship and sustained competitive advantage, and use path analysis to investigate and test their relationships.

\section{LITERATURE SURVEY}

\section{Entrepreneurship}

Joseph Schumpeter (1910) surveyed the relevant literature about entrepreneurs and brought up the term "entrepreneurship". He believed that entrepreneurship is the cause for discovering, driving new combinations of production factors and create social economy. Since then, entrepreneurship has obtained the respect of academic communities. Scholars have no uniform term for entrepreneurship, including entrepreneurship (Schumpeter,1934), corporate entrepreneurship (Miller, 1983), entrepreneurial posture ( Covin \& Slevin, 1991 ) - entrepreneurial strategic posture (Covin, Slevin \& Schultz, 1994), entrepreneurial orientation (Lumpkin \& Dess, 1996), entrepreneurial proclivity (Matsuno, Mentzer and Ozsomer, 2002), etc. Although different terms are used, the meaning is similar. Their purpose is to pursue competitive advantage of enterprises and to enhance business performance. However, after Joseph Schumpeter, most scholars use the constructs and relevant variables presented by Miller \& Friesen (1982) and Miller (1983) when measuring corporate entrepreneurship. And they add different variable aspects for distinct purposes, and therefore expand the contents of entrepreneurship.

Miller (1983) considered that the enterprise that owns entrepreneurship needs to have three characteristics: the first is innovation, including product and process innovation; the second is risk-taking, i.e., the main decision maker of an enterprise needs to have the capability of risk taking; and the third is proactiveness, means an enterprise has the ability to acutely investigate the variation of the environment and adopt strategy to respond in advance. Covin \& Slevin(1989) considered that the values and behaviors of entrepreneurship covers three aspects, i.e., innovativeness, risk-taking, and proactiveness. In this research, we consider that entrepreneurship does not only represent the personal characteristic of the owner or top managers of an enterprise, but also a kind of business culture. Hence, we choose the three aspects: innovativeness, risk-taking, and proactiveness by Miller (1983) and Covin and Slevin (1989) as the measurement aspects of entrepreneurship.

\section{Marketing Capability}

DAY (1994) considered "marketing capability" as the capability of an enterprise to utilize its knowledge, technolodge and resource to satisfy the needs of market or its customers. The success of an enterprise comes from 
the value it creates for its target customers by developing proper products (services) and marketing methods. An enterprise needs to gather market information, improve marketing technologies, upgrade marketing skills and enhance management capabilities to increase its abilities to adapt new challenges from markets. DAY (1994) thought that the capability of an enterprise has close relationship with its organizational processes and organizational capabilities most frequently used in aspects of new product development and service distribution.

Atuahene - Gima (1993) indicated that marketing process often needs to be inspected when analyzing enterprise marketing problems. The process includes: 1.customer service, the purpose of customer service is satisfying needs of users and buyers (Zeithaml \& Bitner, 1996) and to create competitive advantages (Easingwood \& Mahajan,1989; Morris \& Westbrook, 1996); 2.promotion activities, includes advertising, exhibition, propagating, and personal sales, etc. to widely applied in connecting the target markets and increase market share and sales; 3.quality of salesperson, it reflects the skills of salespersons; 4.the extension of marketing network, is related with management capability of channels and relationship with distributors (Vorhies \& Harker, 2000); 5.scope of advertising, the grasp of advertising may influence market share; 6.marketing research, which denote the relevant analysis from the needs of customers to offering of products and services of competitors; 7.capability of product diversification, indicating to upgrade the image other than price, e.g., quality, service; 8.speed of new product appearing in the market, rapid development of new products and services is the key factor of competitive strategies based on innovation (Froehle et al., 2000). These eight processes are used to run their target markets by many various scale enterprises. In this research, we categorize them as the capabilities of customer services, sales, market analysis, and product diversification. The capabilities of marketing can make these marketing processes efficiently operate and could become special competitive advantages.

\section{Innovative Capability}

Drucker (1985a) considered innovation as to give resource new ability to create wealth. It generally needs to combine present resources in a new and productive way. He discussed innovation in more complete and systematical way, and oppose that innovation is a sudden brainstorm. He argued that innovative capability can be trained and learned. Innovation includes two phases, i.e., invention and commercialization. Porter thought that "commercialization is to utilize new method(invention), and innovation process cannot be separated with business strategies and competitive environment (Afuah, 1998) In other words, innovation is what an organization uses to integrate technology, organization and market change so that it can keep exist and develop (Tidd, Bessant, \& Pavitt, 1997).

Innovation can be differentiated by different standards, e.g., administrative and technological innovation; product and process innovation; radical and incremental innovation. Amongst the categorization as administrative and technological innovation has special meaning. It covers social structure factors and technologies (Downs \& Mohr, 1976; Knight, 1967 ; Rowe \& Boise,1974 ; Damanpour, 1991). Furthermore, Weerawardena(2003) considered that an enterprise needs to develop technological innovation as well as non-technological innovation simultaneously. He categorized innovative capabilities as product innovation, process innovation, managerial innovation and marketing innovation.

We consider that Weerawardena's point of view is closer to the direction of this research. Both cover technological innovative and non-technological innovative capabilities. Hence, we categorize innovative capabilities as product innovation, process innovation, managerial innovation and marketing innovation.

\section{Sustained Competitive Advantage}

Competitive advantage in generally indicates that an enterprise can earn more business performance than its competitors in the same industrial area by utilizing its assets and/or competencies. There are two schools of theories about competitive strategies that may affect competitive advantage. One of them is represented by Porter (1994) that explains their positioning theories by competitive strategy structure, and uses "five forces" to analyze the competitive advantage of an industry. They suggest that an enterprise ought to choose a proper industrial position, to make its competitive pressure lighter, or to adopt some actions on its rival firms to earn its own benefits. The other school is resource-based view presented by Wernerfelt ( 1984 ) and emphasized by Prahalad and Hamel (1994). They 
suggest that competitive advantage of an enterprise should build on the basis of its core competences that include tangible and intangible resources.

Jacobson (1988) and Porter (1990) define sustained competitive advantage as competitive advantage that last a rather long period. Such competitive advantage should possess the following characteristics:

1. Sustainability: An enterprise should lead its rival firms and sustain a rather long period, and cannot be run after by its rival firms in rather short period by means of imitating to obtain the same competitive advantage.

2. Uniqueness: An enterprise needs to have the competencies that only owned by small number of firms.

3. Substantiality: An enterprise needs to lead its rival firms with a significant gap.

An enterprise with competitive advantage needs to offer better customer's value and/or lower cost, thus might obtain higher market share and higher financial performance (Hunt and Morgan, 1995). Aharoni (1993) and Porter (1990) suggest to measure competitive advantage by using the index of financial performance. In this study, we use two aspects: firm's profitability and core competencies that hard to imitate, to measure sustained competitive advantage. And firm's profitability is measured by evaluating its consecutive 5 year business performance.

\section{RESEARCH METHOD}

\section{Research Structure}

H3

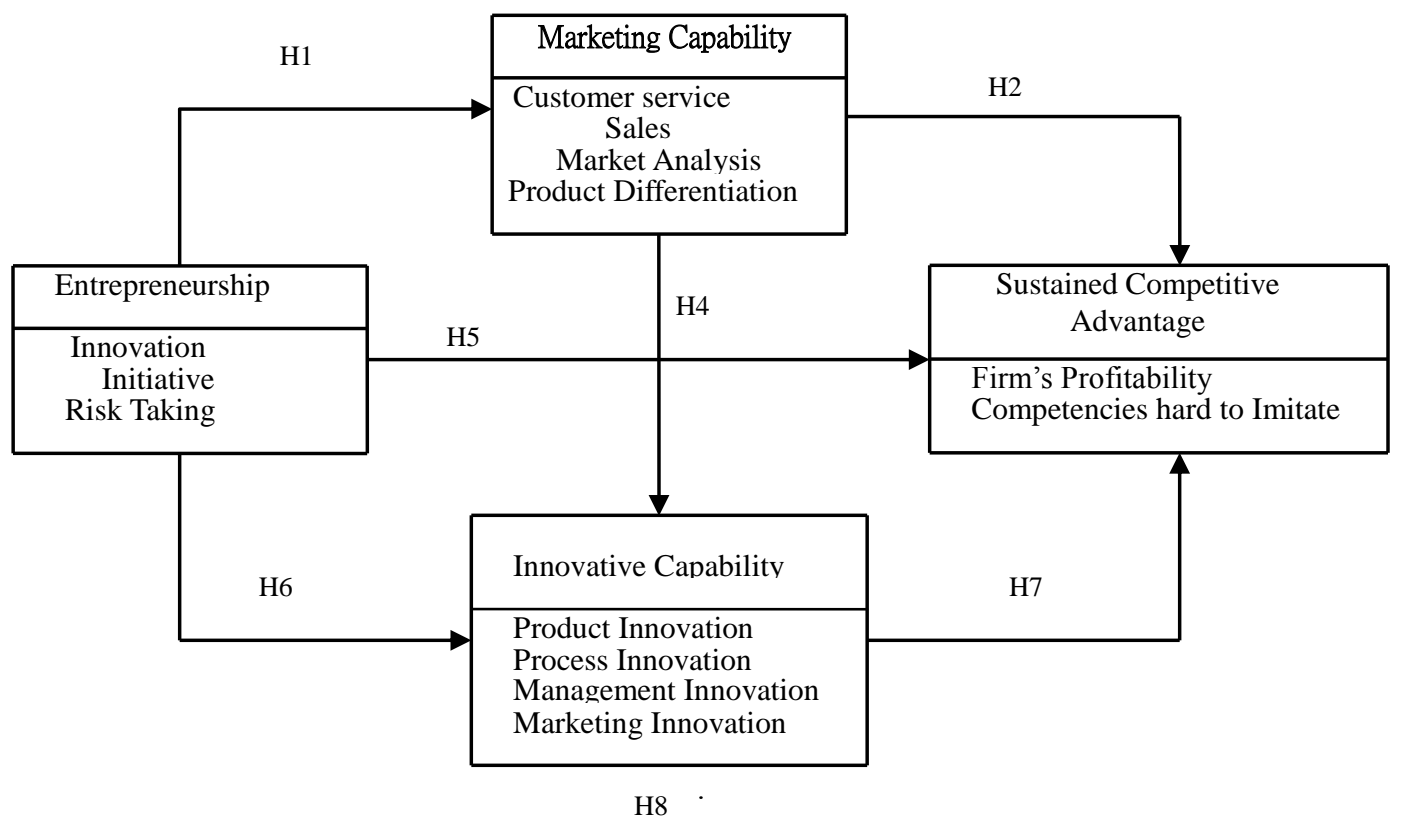

Figure 1 Research Structure

Entrepreneurship, marketing capability and innovative capability might positively impact sustained competitive advantage. By relevant literature, we present a set of hypotheses about the relationships of these constructs and by using path analysis we try to investigate the mediate effects of marketing capability and innovative capability between entrepreneurship and sustained competitive advantage. The research structure is shown as in Figure 1. 


\section{Hypotheses}

(1) The Relationship between entrepreneurship and marketing capability

Liu, Luo and Shi (2002) considered that entrepreneurship is a kind of business culture that might foster a firm to actively enter new markets as well as to introduce new products. No matter entrepreneurship exits in firm's owner, top manager or business culture, the firm will behave more creatively, more initiatively, and more bravely to perform new business. Entrepreneurship plays a critical role for its market orientation capability (Weerawardena \& O'Cass, 2004) and also important for developing new products and services (e.g. Knight, 2000; Kerin, 1992). Therefore, we give the following hypothesis:

H1: Entrepreneurship positively impacts marketing capability

(2) The Relationship between marketing capability and sustained competitive advantage

Many authors suggest that marketing capability of a firm might significantly influence their product and service competitiveness (Day, 1994; Hooly, et al., 1999; Shantanu, et al., 1999; O'Driscoll, et al., 2000). Kerin(1992) points out that marketing plays a very important role in the process of obtaining firm's competitive advantage. The generation of customer value is based on a firm's market benefit study, the choice of target market, the development of product, and market communication and distribution mechanism (Day, 1994; Woodruff, 1997). This relevant capabilities on marketing might improve a firm's products and services (Day, 1994), and therefore generate a firm's specific capability, to make it superior than its competitors (Grant, 1991). Therefore, we give the following hypothesis:

H2: Marketing capability positively impacts sustained competitive advantage

(3) The Relationships of entrepreneurship, marketing capability and sustained competitive advantage hypothesis:

Based on the theories about the prior two hypotheses, we infer the indirect relationship as following

H3: Entrepreneurship positively impacts sustained competitive advantage through marketing capability

4. The Relationship between marketing capability and innovative capability

Kerin (1992) points out that the main role of strategic marketing is innovation. Rizzoni(1991) thought that marketing capability is critical for new product development since the information about customer needs and competitor ought to be considered in the steps of new product development (Song et al., 1996). Many authors suggest that a firm needs to have enough marketing resources and skill in order to develop new products successfully (Calantone, et al. 1993; Atuahene - Gima, 1995). Therefore, we give the following hypothesis:

H4: Marketing capability positively impacts innovative capability

5. The Relationship between entrepreneurship and sustained competitive advantage

Entrepreneurship might be a very important influence factor for a firm's sustained competitive advantage (Weerawardena \& O'Cass, 2004). A firm that owns the characteristics of entrepreneurship generally have better business performance (Khandwalla, 1985). A firm that owns the characteristics of entrepreneurship may agilely investigate the variety of markets and respond more rapidly than its competitors (Namen \& Slevin, 1993). Therefore, we give the following hypothesis:

H5: Entrepreneurship positively impacts sustained competitive advantage

6. The Relationship between entrepreneurship and innovative capability 
Drucker (1985a) suggests that social services or economic activities, as well as public institutes or private firms, all need entrepreneurship to obtain innovation and development. Entrepreneurship may help implement innovative idea, including new products, new services, new production processes, new technologies, new materials and new business models. Therefore, we give the following hypothesis:

H6: Entrepreneurship positively impacts innovative capability

7. The Relationship between innovative capability and sustained competitive advantage

A firm needs to build new idea to promote customer value and obtain competitive advantage (Schumpeter, 1934; Porter, 1990; Rothwell, 1992). AMC(1995) and Hyvarinen(1990) point out that no matter what innovation it might be, technological or non-technological, it can promote a firm's sustained competitive advantage. Therefore, we give the following hypothesis:

H7: Innovative capability positively impacts sustained competitive advantage

8. The Relationships of entrepreneurship, innovative capability and sustained competitive advantage hypothesis:

Based on the theories about the prior two hypotheses, we infer the indirect relationship as following

H8: Entrepreneurship positively impacts sustained competitive advantage through innovative capability

9. The Relationships of entrepreneurship, marketing capability, innovative capability and sustained competitive advantage hypothesis:

Based on the theories about the prior two hypotheses, we infer the indirect relationship as following

H9: Entrepreneurship positively impacts sustained competitive advantage through marketing capability and innovative capability

\section{RESULTS}

\section{Population and Sample Selection}

We investigate the top 1000 Taiwanese manufacturers issued by Commonwealth magazine of Taiwan in 2009 to precede an empirical study. In total, 1000 questionnaires were mailed to senior or middle managers, and 118 complete questionnaires returned (the return rate is $11.6 \%$ ). The industries of sample firms include mechanics, computer and electronics, automobiles, electrical engineering, food, clothing, chemical, steel and metal manufacturers. A pilot test was also performed to enhance the validity.

\section{Reliability and Validity}

We use the Cronbach's $\alpha$ for examining the reliability of the instruments. The Cronbach's $\alpha$ of all the constructs are shown in Table 1, in which all constructs including entrepreneurship, marketing capability, innovative capability and sustained competitive advantage have higher than .7 cut off alpha value, ranging from .72 to .89 . A confirmatory factor analysis (CFA) was performed to assess and validate the measurement of factors included in the model.

Table 1 Cronbach's $\alpha$

\begin{tabular}{|l|c|c|c|c|}
\hline & Entrepreneurship & $\begin{array}{c}\text { Marketing } \\
\text { Capability }\end{array}$ & $\begin{array}{c}\text { Innovative } \\
\text { Capability }\end{array}$ & $\begin{array}{c}\text { Sustained Competitive } \\
\text { Advantage }\end{array}$ \\
\hline Cronbach's $\alpha$ & .72 & .82 & .85 & .89 \\
\hline
\end{tabular}




\section{Structural Equation Modeling (SEM)}

We use structural equation modeling (SEM) and maximum method to build and analyze the structural model, and LISREL 8.7 of software for data analyses is used to verify the hypotheses. The structure equation model is shown in figure 2.

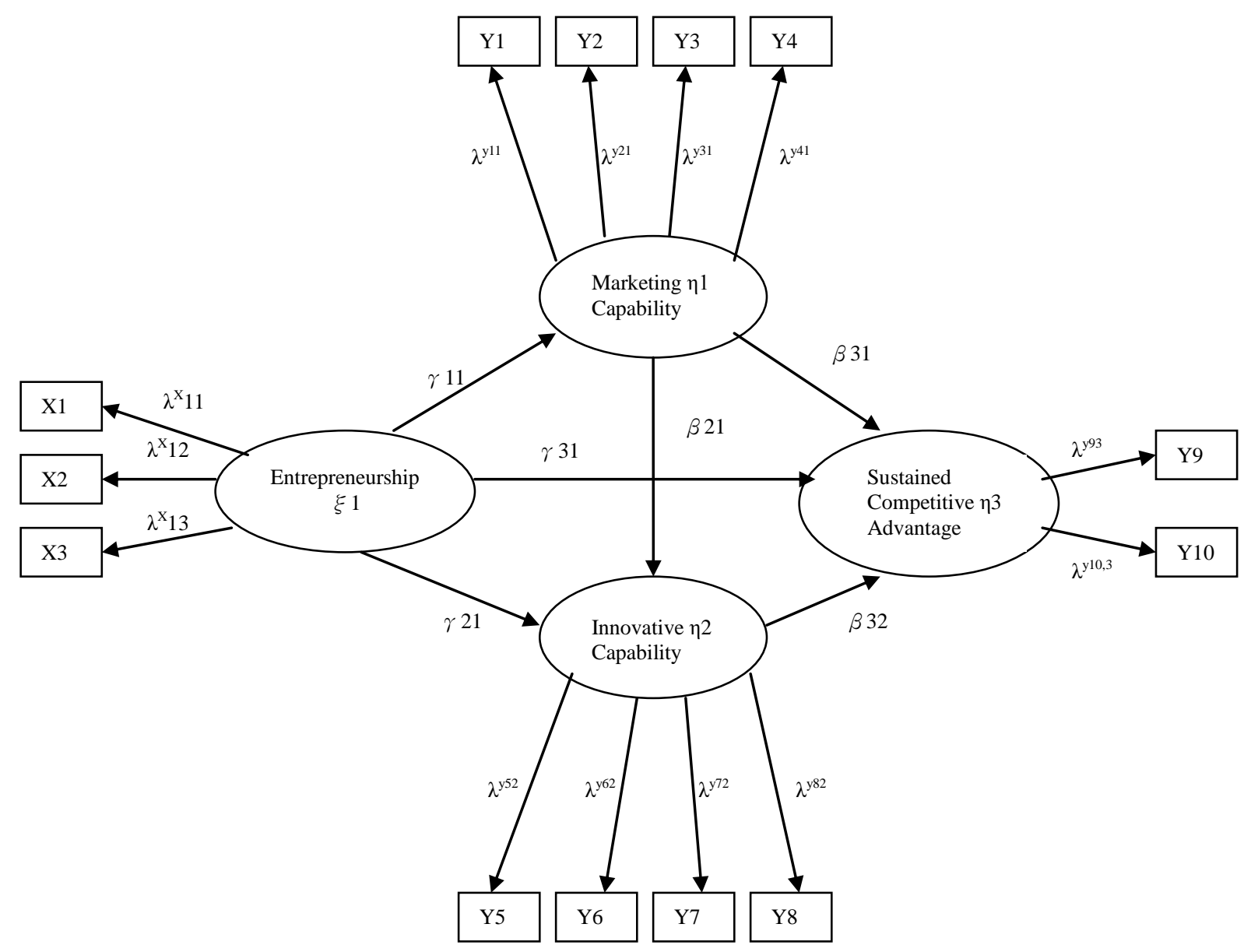

Figure 2 Structural Equation Model

All the model-fit indexes in Table 2 show that the model is fitted well.

Table 2: Model-Fit Evaluation

\begin{tabular}{|c|c|c|}
\hline Model-Fit Index & Criteria & Index value \\
\hline$\chi^{2} / \mathrm{df}$ & $<2$ & 0.90 \\
\hline GFI & $>.90$ & 0.85 \\
\hline AGFI & $>.90$ & 0.94 \\
\hline NFI & $>.90$ & 0.97 \\
\hline NNFI & $>.90$ & 0.98 \\
\hline CFI & $>.90$ & 0.058 \\
\hline RMSEA & $<.06$ & .06 \\
\hline SRMR & $<.08$ & 0.035 \\
\hline RMR & $<.05$ & \\
\hline
\end{tabular}


In the model, the estimates of parameters $\gamma_{11}, \gamma_{21}, \gamma_{31}, \beta_{21}$ and $\beta_{32}$ are significant as shown in Table 3.

Table 3 Estimates of Parameter $\gamma \cdot \beta$

\begin{tabular}{|c|c|c|c|}
\hline Parameters & Estimates & T values & Significant Level \\
\hline$\gamma 11$ & .85 & 6.01 & $* * *$ \\
\hline$\gamma 21$ & .44 & 1.83 & + \\
\hline$\gamma 31$ & .52 & 1.75 & + \\
\hline$\beta 21$ & .42 & 1.77 & + \\
\hline$\beta 31$ & .15 & .59 & $\times$ \\
\hline$\beta 32$ & .38 & 1.90 & + \\
\hline
\end{tabular}

$+\mathrm{p}<.1(1.645 \leqq \mathrm{t}<1.96) ; * \mathrm{p}<.05(1.96 \leqq \mathrm{t}<2.58) ; * * \mathrm{p}<.01(2.58 \leqq \mathrm{t}<3.29) ; * * * \mathrm{p}<.001(3.29 \leqq \mathrm{t})$

\section{Results of Empirical Study}

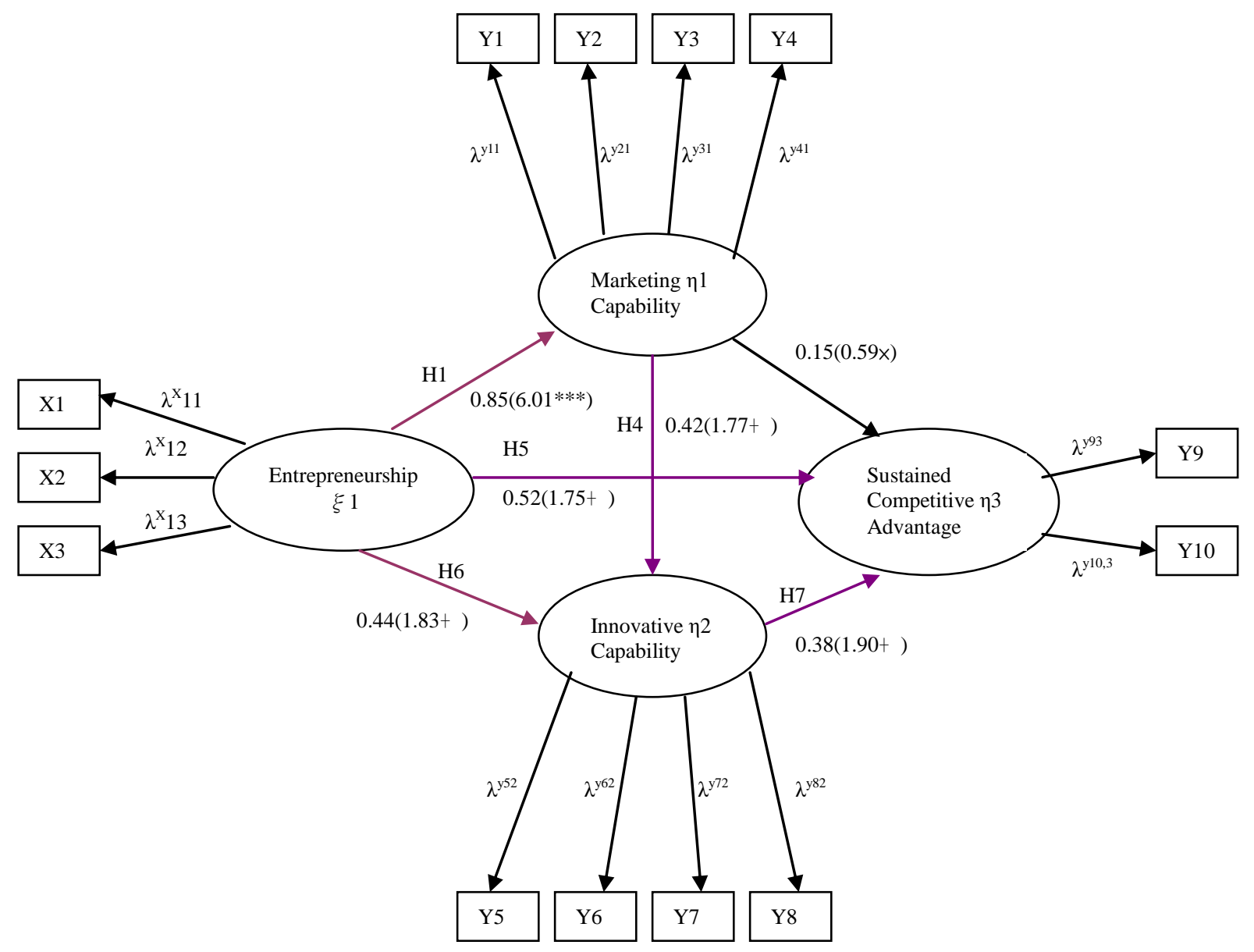

Figure 3 Results of SEM 
Table 4 SEM Path Analysis

\begin{tabular}{|l|c|c|c|}
\hline \multicolumn{1}{|c|}{ Hypotheses and Path } & t-value & Significance & Results \\
\hline H1 $:$ Entrepreneurship positively impacts marketing capability $(\gamma 11)$ & 6.01 & $* * *$ & OK \\
\hline H2 $:$ Marketing capability positively impacts sustained competitive advantage $(\beta 31)$ & .59 & $\times$ & Rej \\
\hline $\begin{array}{l}\text { H3 : Entrepreneurship positively impacts sustained competitive advantage through } \\
\text { marketing capability }(\gamma 11 \rightarrow \beta 31)\end{array}$ & $6.01 \rightarrow .59$ & $* * * \rightarrow \times$ & Rej \\
\hline H4: Marketing capability positively impacts innovative capability $(\beta 21)$ & 1.77 & + & OK \\
\hline H5 : Entrepreneurship positively impacts sustained competitive advantage $(\gamma 31)$ & 1.75 & + & OK \\
\hline H6 : Entrepreneurship positively impacts innovative capability $(\gamma 21)$ & 1.83 & + & OK \\
\hline H7 $:$ Innovative capability positively impacts sustained competitive advantage $(\beta 32)$ & 1.90 & + & OK \\
\hline $\begin{array}{l}\text { H8: Entrepreneurship positively impacts sustained competitive advantage through } \\
\text { innovative capability }(\gamma 21 \rightarrow \beta 32)\end{array}$ & $1.83 \rightarrow 1.90$ & $+\rightarrow+$ & OK \\
\hline $\begin{array}{l}\text { H9 }: \text { Entrepreneurship positively impacts sustained competitive advantage through } \\
\text { marketing capability and innovative capability }(\gamma 11 \rightarrow \beta 21 \rightarrow \beta 32)\end{array}$ & $1.83 \rightarrow 1.90$ & $+\rightarrow+\rightarrow+$ & OK \\
\hline
\end{tabular}

\section{CONCLUSIONS}

In this study, we investigate the relationships of entrepreneurship, marketing capability, innovative capability, and sustained competitive advantage. Based on structural equation modeling and LISREL 8.7 of software for data analyses, we obtain the conclusions: 1.entrepreneurship directly influence marketing capability, innovative capability and sustained competitive advantage respectively; and indirectly influence sustained competitive advantage through marketing capability and innovative capability respectively; 2.although marketing capability does not influence sustained competitive advantage directly, but influence sustained competitive advantages indirectly through innovative capability; in the other way, innovative capability influence sustained competitive advantage directly. Therefore, we suggest that an enterprise needs to develop its organizational culture of entrepreneurship and the two kinds of capabilities, marketing and innovation, hopefully to enhance its sustained competitive advantage.

\section{AUTHOR INFORMATION}

Jia-Sheng Lee, Head of the Department of Business Administration, Providence University of Taiwan, R.O.C. Dr. Lee teaches courses in Business Administration and Technology Management, and has authored or co-authored many articles in refereed journals or conference proceedings.

Chia-Jung Hsieh, Area Sales Manager, TRUMPF Taiwan Industries Co., Ltd. Mr. Hsieh has engaged the sales job for more ten years, and is now responsible for Machine Tools and Power Tools at Taiwan market.

\section{REFERENCES}

1. Afuah, A. (1998), Innovation Management: Strategies, Implementation, and Profits, New York: Oxford University Press.

2. Aharoni, Y. (1993), "In Search for the Unique: Can Firm-Specific Advantages Be Evaluated?", Journal of Management Studies 30, no.1.

3. AMC (1995), The Innovation Cycle: Practical Tips from Innovative Firms, Australian Manufacturing Council.

4. Atuahene-Gima, K. (1993), "Determinants of Technology Licensing Intentions: an Empirical Analysis of Australian Engineering Firms", Journal of Product Innovation Management 10, 230-240.

5. Atuahene-Gima, K. (1995), "An Exploratory Analysis of the Impact of Market Orientation on New Product Performance: a Contingency Approach", Journal of Product Innovation Management 12, 275-93.

6. Calantone, R.J. and Di Benedetto, C.A. (1988), "An Integrative Model of the New Product Development Process", Journal of Product Innovation Management 5(September), 201-215.

7. Calantone, R.J., Di Benedetto, C.A. and Divine, R. (1993), “Organizational, Technical and Marketing Antecedents for Successful New Product Development”, R\&D Management 23, no.4. 
8. Chang, T. (1996), "Cultivating Global Experience Curve Advantage on Technology and Marketing Capabilities", International Marketing Review 13, no.6, $22-42$.

9. Covin, J.G. and D.P. Slevin (1989), "Strategic Management of Small Firms in Hostile and Benign Environments", Strategic Management Journal 10, no.1, 75-87

10. Covin, J.G. and D.P. Slevin (1991), "A Conceptual Model of Entrepreneurship as Firm Behavior", Entrepreneurship Theory and Practice 15, no.4, 35-50.

11. Covin, J.G., D.P. Slevin, and R.L. Schultz1 (1994), "Implementing Strategic Mission: Effective Strategic, Structural and Tactical Choices", The Journal of Management Studies 31, 481-505.

12. Damanpour, F. (1991), "Organizational Innovation: a Meta Analysis of Effects of Determinants and Moderators", Academy of Management Journal 34, no.3, 555-590.

13. Day, G.S. (1992), "Marketing's Contribution to the Strategy Dialogue", Journal of the Academy of Marketing Science 20, no.4, 323-29.

14. Day, G.S. (1994), "The Capabilities of the Market - Driven Organization", Journal of Marketing 58, 37-51.

15. Downs, G.W., and L.B. Mohr (1976), "Conceptual Issues in the Study of Innovation", Administrative Science Quarterly 21, 700-714.

16. Drucker, P.F. (1985), "Innovation and Entrepreneurship: Practice and Principles", Harvard Business Review 76, no.6, 149-157.

17. Drucker, E.P. (1985), “The Discipline of Innovation”, Harvard Business Review, 67-72.

18. Easingwood, C.J. and Mahajan, V. (1989), "Positioning of Financial Services for Competitive Advantage", Journal of Product Innovation Management 6, no.3, 207-19.

19. Froehle, C.M., A.V. Roth, R.B. Chase, and C.A. Voss (2000), "Antecedents of New Service Development Effectiveness: An Exploratory Examination of Strategic Operations Choices", Journal of Services Research 3(August), no.1.

20. Grant, R. M. (1991), "The Resource-Based Theory of Competitive Advantage: Implications for Strategy Formulation", California Management Review 33, no.3, 114-135.

21. Hitt, M.A., R.D. Ireland and R.E. Hoskisson (2001), Strategic Management : Competitiveness and Globalization, 4th ed., South-Western.

22. Hooly, G., J. Fahy, Cox, J. Beracs, K. Fonfara, and B. Snoj (1999), "Marketing Capabilities and Firm Performance: a Hierarchical Model", Journal of Market Focused Management 4, 259-78

23. Hunt, S.D. and R.M. Morgan (1995), "The Comparative Advantage Theory of Competition", Journal of Marketing 59(April), 1-15.

24. Hyvarinen, L. (1990), "Innovativeness and Its Indicators in Small and Medium-Sized Industrial Enterprises", International Small Business Journal 9(1), 64-74.

25. Jacobson, R. (1988), “The Persistence of Abnormal Returns”, Strategic Management Journal 9, 41-58.

26. Kapferer, J.N. (1992), Strategic Brand Management, NY: The Free Press.

27. Kerin, R.A.(1992), "Marketing's Contribution to the Strategy Dialogue Revisited", Journal of the Academy of Marketing Science 20(4), 331-34.

28. Khandwalla, P.N. (1985), "Pioneering Innovative Management: An Indian Excellence." Organization Studies, 6, no.2, 161-183.

29. Knight, G. (2000), "Entrepreneurship and Marketing Strategy: the SME under Globalization", Journal of International Marketing 8, no.2, 12-32.

30. Knight, K. E. (1967), “A Descriptive Model of the Intra-Firm Innovation Process", Journal of Business 4, 478-496.

31. Liu, S., X. Luo, and Y. Shi (2002), "Integrating Customer Orientation, Corporate Entrepreneurship, and Learning Orientation in Organization-in-Transition: an Empirical Study", Internal Journal of Research in Marketing 19, 367-382.

32. Lumpkin, G. T. and G. G. Dess (1996), "Clarifying the Entrepreneurial Orientation Construct and Linking It to Performance", The Academy of Management Review 21, no.1, 135-172.

33. Matsuno, K., J. T. Mentzer, and Ozsomer (2002), “The Effect Of Entrepreneurial Proclivity and Market Orientation on Business Performance", Journal of Marketing, 66, no.3, 18-32.

34. Miller, D. and P. H. Friesen (1982), "Innovation in Conservative and Entrepreneurial Firms: Two Models of Strategic Momentum", Strategic Management Journal 3, no.1, 1-25.

35. Miller, D.(1983), "The Correlates of Entrepreneurship in Three Types of Firms", Management Science 29, no.7, 770-791. 
36. Morris, T. and R. Westbrook (1996), "Technical Innovation and Competitive Advantage in Retail Financial Services: A Case Study of Change and Industry Response”, British Journal of Management 7, no.1, 45-61.

37. Naman, J.L and D.P. Slevin (1993), "Entrepreneurship and the Concept of Fit: A Model and Empirical Tests", Strategic Management Journal 14, no.2, 137-53.

38. O'Driscoll, A., D. Carson, and A. Gilmore(2000), "Developing Marketing Competence and Managing in Networks: A Strategic Perspective", Journal of Strategic Marketing 8, 183-196.

39. Porter, M.E. (1990), Competitive Advantage: Creating and Sustaining Superior Performance, New York: Free Press.

40. Rizzoni, A. (1991), “Technological Innovation and Small Firms: A Taxonomy”, International Small Business Journal 9, no.3, 31-42.

41. Rothwell, R. (1992), "Successful Industrial Innovation: Critical Factors for the 1990s", Research and Development Management 22, no3, 221-239.

42. Rowe, L.A. \& W.B. Boise (1974), "Organizational Innovation: Current Research and Evolving Concepts", Public Administration Review 34, 284-293.

43. Schmidt, J.B. (1995), "New Product Myopia: Which Activities Determine Success?”, Journal of Business and Industrial Marketing 10, no.1, 23-33.

44. Schumpeter, J.A. (1934), The Theory of Economic Development, Cambridge, Massachusetts: Harvard University Press.

45. Shantanu, D., N. Om and R. Surendra (1999), "Success in High-Technology Markets: Is Marketing Capability Critical?", Marketing Science 18, no.4, 547-568.

46. Song, X.M. and M.E. Parry (1993), "R\&D - Marketing Integration Japanese High-Technology Firms: Hypotheses and Empirical Evidence”, Journal of the Academy of Marketing Science_21(Spring), 125-33.

47. Song, X.M., S.M. Neely and Y. Zhao (1996), "Marketing R\&D - Marketing Integration in the New Product Development Process", Industrial Marketing Management 25, 545-553.

48. Statistics Canada (1994), "Strategies for Success: A Profile of Growing Small and Medium-Sized Enterprises (GSMEs) in Canada", Minister of Industry, Science and Technology.

49. Tidd, J., J. Bessant, and K. Pavitt (1997), Managing Innovation: Integrating Technological, Market and Organizational Change, Chichester, New York: John Wiley.

50. Vorhies, D.W. and M. Harker (2000), "The Capabilities and Performance Advantages of Market-Driven Firms: an Empirical Investigation", Australian Journal of Management 25(September), no.2.

51. Weerawardena, J. (2003), "The Role of Marketing Capability in Innovation - Based Competitive Strategy", Journal of Strategy Marketing 11, 15-35

52. Weerawardena, J. and A. O'Cass (2004), "Exploring the Characteristics of the Market-Driven Firms and Antecedents to Sustained Competitive Advantage" Industrial Marketing Management 33 419- 428.

53. Wernerfelt, B. (1984), "The Resource-Based View of the Firm”, Strategic Management Journal, 5, 171-180.

54. Woodruff, R.B. (1997), "Customer Value: the Next Source of Competitive Advantage", Journal of the Academy of Marketing Science 25(Spring), 139-153.

55. Zeithaml, V.A. and M.J. Bitner (1996), Services Marketing, Sydney: McGraw-Hill. 
NOTES 